\title{
ANALISIS DAYA SAING PERIKANAN CAKALANG (KATSUWONUS PELAMIS) PADA ALAT TANGKAP PURSE SEINE
}

\author{
Fajriah(1), Azhar Bafadal (2), La Anadi (3) $^{(1)}$
}

(1)FPIK, Universitas Muhammadiyah Kendari, (2) Jurusan Agribisnis, Fakultas Pertanian Univ. Halu Oleo, (3) FPIK Univ. Halu Oleo

\begin{abstract}
Skipjack fishery business is one of businesses in catch fisheries sector which is potential to be developed since it has the ability to increase fishermen's income and macro economy. This research was aimed to analyze: a) Competitiveness of skipjack fisheries bussines the Purse Seine Fishermen Capture Device Kendari at WPP 714 on comparative and competitive advantages, $b$ ) the impact of policy on the competitiveness of skipjack fishery business in Kendari. The research was carried out for seven months from December 2013 to July 2014 in Kendari, the center of catch fisheries in Southeast Sulawesi. The sampling is done by simple random sampling. The data was analyzed by using Policy Matrix Analysis (PAM) model.

The result showed that; Skipjack fishery business using in Kendari has a good competitiveness in both domestic and international market. This result implied that the skipjack fishery business in Kendari is economically and financially feasible, and will become more competitive if supported by government's policy on input and output prices of the skipjack fishery business.
\end{abstract}

Key words: competitive, financial, economy, impact of policy

\section{PENDAHULUAN}

erikanan merupakan bagian penting dalam kehidupan masyarakat Indonesia. Usaha Peningkatan produksi ikan semakin digalakkan dalam rangka memenuhi kebutuhan protein dari penduduk yang semakin bertambah. Disamping kebutuhan devisa yang mendesak, lahan dan potensi perikanan masih memungkinkan untuk tujuan itu utamanya disektor perikanan tangkap. Dugaan potensi lestari sumberdaya ikan laut di perairan Indonesia adalah sebesar 6,26 juta QE Journal | Vol.03 - No.04 December 2014 - 217 
ton per tahun, dengan tingkat pemanfaatan potensi diduga mencapai $60 \%$ (Kusumastanto, 2011).

Peningkatan produktivitas perikanan tangkap ini bergantung pada usaha perikanan tangkap yang selanjutnya diharapkan dapat mendukung peningkatan pendapatan nelayan. Model perikanan tangkap yang seharusnya diusahakan adalah yang bersifat menguntungkan seluruh pelaku usaha. Produk yang dihasilkan kompetitif baik di pasar domestik maupun global selanjutnya berkelanjutan, artinya kelestarian sumber daya ikan dan ekosistemnya terpelihara dengan baik sehingga usaha perikanan tangkap dapat berlangsung secara berkelanjutan (sustainable).

Ikan cakalang (Katsuwonus pelamis) merupakan salah satu potensi sumberdaya perikanan tangkap yang memiliki nilai ekonomi tinggi karena disukai masyarakat pada umumnya. Ikan cakalang umumnya hidup di perairan laut tropis yang hangat seperti kondisi perairan Indonesia, hampir diseluruh Wilayah Pengelolaan Perikanan (WPP) Indonesia menjadi daerah migrasi atau ruaya ikan cakalang (KKP, 2012). Potensi Perikanan tersebut menjadikan Indonesia sebagai negara pengekspor tuna dan cakalang. Negara tujuan ekspornya antara lain USA, Philipina, Thailand dan Uni Eropa sedangkan negara pesaing Indonesia di pasar Internasional yakni Australia, Spanyol, Korea Selatan, Taiwan dan Guam (Cahya, 2010).

Kota Kendari merupakan salah satu sentra aktivitas sektor perikanan tangkap di Sulawesi Tenggara, hal ini didukung oleh sarana dan prasarana seperti pelabuhan perikanan tipe A yang dimiliki yakni Pelabuhan Perikanan Samudera (PPS) Kendari yang memadai (Ira, 2014). Salah satu alat tangkap ikan cakalang yang banyak digunakan nelayan hingga kini adalah Pukat cincin (Purse seine) dengan kapasitas armada $\geq 30$ GT, diduga karena alat tangkap purse seine mampu memberikan keuntungan dan meningkatkan pendapatan nelayan (Lopulalan, 2010). Dengan penerapan teknologi penangkapan yang baik pada jenis alat tangkap ini diharapkan ikan cakalang hasil tangkapan nelayan Kota Kendari mampu menjadi komoditas yang memiliki daya saing yang tidak kalah dengan komoditi ikan cakalang hasil tangkapan nelayan didaerah lain dalam rangka menghadapi era globalisasi dan perdagangan bebas.

Dalam perdagangan bebas situasi dunia akan sangat berpengaruh terhadap dinamika daya saing produk yang dihasilkan oleh setiap negara 
(Sugiyanto, 2004). Kebijakan pemerintah juga sangat mempengaruhi peningkatan keunggulan komparatif dan kompetitif suatu usaha dalam hal ini perikanan tangkap ikan cakalang baik ditingkat produksi maupun perdagangan. Kebijakan pemerintah seperti penerapan tarif impor, subsidi, pajak ekspor dan lain-lain merupakan faktor eksternal yang dapat mempengaruhi pengembangan usaha perikanan tangkap ikan cakalang. Berlandaskan hal tersebut maka tujuan dari penelitian ini adalah untuk menganalisis daya saing perikanan cakalang pada alat tangkap purse seine nelayan Kota Kendari berdasarkan keunggulan komparatif dan kompetitif dan menganalisis dampak kebijakan pemerintah terhadap daya saing usaha perikanan cakalang pada alat tangkap purse seine di Kota Kendari.

\section{METODE PENELITIAN}

Penelitian dilaksanakan di Kota Kendari Provinsi Sulawesi Tenggara, pada tahun 2014. Populasi pada penelitian ini adalah nelayan pemilik kapal penangkap ikan cakalang pada kapal purse seine yang berukuran 30 GT keatas sebanyak 20 orang. Adapun penentuan jumlah sampel secara keseluruhan dilakukan dengan menggunakan rumus Slovin sehingga menghasilkan jumlah sampel 13 pemilik kapal pada alat tangkap purse seine.

Untuk menjawab tujuan pertama dan kedua pada penelitian ini digunakan analisis kuantitatif melalui analisis Policy Analysis Matrix (PAM) sebagaimana disajikan pada Tabel 2.1

Tabel 1. Analisis Policy Analysis Matrix (PAM)

\begin{tabular}{lcccc}
\hline Deskripsi & $\begin{array}{c}\text { Penerimaan } \\
(\mathrm{RP})\end{array}$ & $\begin{array}{c}\text { Biaya input } \\
\text { Tradable }(\mathrm{Rp})\end{array}$ & $\begin{array}{c}\text { Biaya input non } \\
\text { tradable }(\mathrm{Rp})\end{array}$ & $\begin{array}{c}\text { Keuntungan } \\
(\mathrm{Rp})\end{array}$ \\
\hline Harga privat & $\mathrm{A}$ & $\mathrm{B}$ & $\mathrm{C}$ & $\mathrm{D}$ \\
Harga Sosial & $\mathrm{E}$ & $\mathrm{F}$ & $\mathrm{G}$ & $\mathrm{H}$ \\
Dampak kebijakan & $\mathrm{I}$ & $\mathrm{J}$ & $\mathrm{K}$ & $\mathrm{L}$ \\
\hline
\end{tabular}

Sumber : Pearson et al (2005)

Keterangan :

1. Analisa Keuntungan :

a. Keuntungan Privat $(\mathrm{PP}) \mathrm{D}=(\mathrm{A})-(\mathrm{B})-(\mathrm{C})$

b. Keuntungan Sosial (PS) $H=(E)-(F)-(G)$ 
2. Analisa Daya saing:

a. Privat Cost Ratio $(\mathrm{PCR})=\frac{\mathrm{C}}{\mathrm{A}-\mathrm{B}}$

b. Domestic Resource Cost Ratio $(\mathrm{DRC})=\frac{\mathrm{G}}{\mathrm{E}-\mathrm{F}}$

3. Analisis Dampak Kebijakan Input :

a. Transfer Input : IT = B - F

b. Nominal Protection Coefficient to Input $: \mathrm{NPCI}=\frac{\mathrm{B}}{\mathrm{F}}$

c. Transfer Faktor: FT=C - G

4. Kebijakan output :

a. Output Transfer: OT = A-E

b. Nominal Protection Cofficient Output : $\mathrm{NPCO}=\frac{\mathrm{A}}{\mathrm{E}}$

5. Kebijakan Input-Output

a. Effective Protection Coefficient: $\mathrm{EPC}=\frac{\mathrm{A}-\mathrm{B}}{\mathrm{E}-\mathrm{F}}$

b. Net Transfer : NT $=\mathrm{D}-\mathrm{H}$

c. Profitability Coefficient: $\mathrm{PC}=\frac{\mathrm{D}}{\mathrm{H}}$

\section{HASIL DAN PEMBAHASAN}

\section{Analisis Daya Saing Usaha Perikanan Cakalang}

Analisis keunggulan komparatif dan kompetitif usaha perikanan ikan cakalang Kota Kendari menggunakan asumsi ekonomi makro sesuai pada analisis Policy Analysis Matrix (PAM), yakni tingkat suku bunga nominal 13 $\%$ per tahun, tingkat suku bunga sosial $22,25 \%$ per tahun dan nilai tukar Rupiah per US Dollar yakni Rp.11.425 pada tahun 2014 (Bank Indonesia dan Kementrian Koordinator bidang Perekonomian, 2014).

Tingkat suku bunga nominal (nominal interest rate) diperoleh dari informasi tingkat kredit formal (bank persero, bank pemerintah daerah, bank swasta nasional, bank umum dan lembaga kredit lainnya). Tingkat suku bunga sosial (social interest rate) merupakan penjumlahan dari social opportunity cost of capital yang diasumsikan sebesar $15 \%$ per tahun ditambah dengan laju inflasi nasional pada tahun penelitian (Pearson et al, 2005). Laju inflasi nasional tahun 2014 yakni sebesar 7,25\% dengan demikian tingkat suku bunga sosial berada pada besaran 22,25 \% per tahun (Kementerian Keuangan RI, 2014). 
Sesuai dengan rumus untuk menghitung keunggulan komparatif dan kompetitif suatu komoditas atau usaha maka langkah-langkah yang perlu dilakukan lebih dahulu adalah : (a) mengelompokkan input-input usaha perikanan cakalang ke dalam kategori input tradable dan kategori non tradable input, (b) melakukan perhitungan nilai dan keuntungan privat serta nilai dan keuntungan ekonomis yang selanjutnya akan digunakan untuk menghitung transfer input dan output (Amrun, 2011).

\section{Perhitungan Harga Privat}

Harga privat dalam analisis keunggulan komparatif dan kompetitif adalah nilai atau harga input dan output usaha perikanan yang berlaku di lokasi penelitian pada saat dilakukan penelitian.

Harga rata-rata ikan cakalang di Kota Kendari pada saat penelitian dilakukan adalah Rp12.000,-/kg. Secara rinci data mengenai jumlah serta harga privat untuk input dan output usaha perikanan cakalang dengan alat tangkap Purse Seine (PS) di Kota Kendari pada tahun 2014 disajikan pada Tabel 3.2. Pada Tabel 3.3 nampak bahwa rata-rata pendapatan bersih atau keuntungan privat (PP) yang diperoleh para pemilik kapal cukup besar. Dari hasil penangkapan ikan cakalang pemilik kapal penangkapan ikan cakalang pemilik kapal purse seine meraup keuntungan sebesar Rp4.041.221,- per trip. 
Tabel 2. Jumlah dan Harga Privat untuk Tradable input, non tradable input, dan output Usaha Perikanan Cakalang di Kota Kendari pada Bulan Maret - Mei 2014

Tradable input

Non tradable input

\begin{tabular}{|c|c|c|c|c|c|c|c|}
\hline $\begin{array}{c}\text { Jenis dan } \\
\text { Satuan }\end{array}$ & $\begin{array}{l}\text { Jumlah } \\
\text { per trip }\end{array}$ & $\begin{array}{l}\text { Harga } \\
\text { per } \\
\text { unit } \\
(\mathrm{Rp})\end{array}$ & $\begin{array}{c}\text { Total nilai } \\
(\mathrm{Rp} / \text { trip })\end{array}$ & $\begin{array}{c}\text { Jenis dan } \\
\text { Satuan }\end{array}$ & $\begin{array}{l}\text { Jumlah } \\
\text { per trip }\end{array}$ & $\begin{array}{l}\text { Harga } \\
\text { per } \\
\text { unit } \\
(\mathrm{Rp})\end{array}$ & $\begin{array}{c}\text { Total nilai } \\
\text { (Rp/trip) }\end{array}$ \\
\hline a.Solar (Ltr) & 1300 & 5.500 & 7.150 .000 & Air bersih & 3 & 4.194 & 12.582 \\
\hline b.Oli (Ltr) & 15 & 22.500 & 337.500 & Es balok & 75 & 15.000 & 1.125 .000 \\
\hline c.Bensin (Ltr) & 30 & 6.500 & 195.000 & $\begin{array}{l}\text { Umpan } \\
\text { buatan }\end{array}$ & & $\begin{array}{l}- \\
-\end{array}$ & - \\
\hline $\begin{array}{l}\text { d.Minyak } \\
\quad \text { tanah (Ltr) }\end{array}$ & $\begin{array}{l}10 \\
1,25\end{array}$ & $\begin{array}{l}7.000 \\
6.000\end{array}$ & $\begin{array}{l}70.000 \\
7.500\end{array}$ & $\begin{array}{l}\text { Umpan } \\
\text { hidup }\end{array}$ & $\begin{array}{c}28 \\
2.432 .667\end{array}$ & $\begin{array}{l}320.959 \\
-\end{array}$ & $\begin{array}{l}6.508 .791 \\
2.432 .667\end{array}$ \\
\hline $\begin{array}{l}\text { e. Garam (Kg) } \\
\text { f. Beras }(\mathrm{Kg})\end{array}$ & $\begin{array}{l}35 \\
28\end{array}$ & $\begin{array}{r}9.000 \\
14.882\end{array}$ & $\begin{array}{l}315.000 \\
416.696\end{array}$ & $\begin{array}{l}\text { Tenaga kerja } \\
\text { Pemulihan }\end{array}$ & 150.000 & - & $\frac{150.000}{12.707 .101}$ \\
\hline $\begin{array}{l}\text { g. Telur } \\
\text { (lusin) } \\
\text { h.Mie instant } \\
\quad \text { (dos) } \\
\text { i.Pemulihan } \\
\quad \text { modal } \\
\text { peralatan } \\
\text { (Rp) }\end{array}$ & $\begin{array}{c}7 \\
553.083\end{array}$ & $\begin{array}{l}75.240 \\
-\end{array}$ & $\begin{array}{c}526.680 \\
\underline{553.083} \\
9.571 .459\end{array}$ & $\begin{array}{l}\text { modal } \\
\text { peralatan }\end{array}$ & & & \\
\hline
\end{tabular}

\section{Perhitungan Harga Sosial}

Harga sosial atau nilai ekonomis adalah border price atau harga perbatasan dari barang-barang yang dapat diperdagangkan antar negara (tradable goods) (Gittinger, 1986). Harga perbatasan yang digunakan adalah harga free on board ( $f o b)$ antara lain pada berbagai jenis mesin, konsumsi dan komoditi ikan cakalang dan cost,insurance and freight (cif). Penggunaan harga fob pada output ikan cakalang karena diasumsikan bahwa ikan cakalang yang didaratkan di PPS dan TPI Kota Kendari potensil untuk diekspor. Terdapat pula harga sosial yang merupakan harga pada pasar persaingan sempurna atau harga yang tidak didistorsi oleh kebijakan pemerintah berupa subsidi seperti pada harga BBM. Data mengenai nilai fob, cif dan harga sosial BBM yang diperoleh dari Badan Pusat Statistik 
Provinsi Sulawesi Tenggara, Kementerian Energi Sumber Daya Mineral, Departemen Perindustrian serta berbagai sumber melalui browsing internet adalah seperti pada Tabel 3 .

Tabel 3. Nilai fob dan cif input dan output Usaha Perikanan Cakalang Tahun 2014

\begin{tabular}{|c|c|c|c|}
\hline No. & Jenis dan satuan Input dan output & $\begin{array}{l}\text { Border price per } \\
\text { satuan /unit }(\$)^{*}\end{array}$ & $\begin{array}{c}\text { Border price per } \\
\text { satuan /unit } \\
(\mathrm{Rp})\end{array}$ \\
\hline 1. & Solar (Ltr) & 0,88 & 10.000 \\
\hline 2. & Oli (Ltr) & 2,01 & 23.000 \\
\hline 3. & Bensin (Ltr) & 0,88 & 10.000 \\
\hline 4. & Minyak tanah (Ltr) & 0,85 & 9.700 \\
\hline 5. & Beras $(\mathrm{kg})$ & 0,53 & 6.000 \\
\hline 6. & Telur (Lusin) & 1,45 & 16.549 \\
\hline 7. & Garam $(\mathrm{Kg})$ & 0,12 & 1.366 \\
\hline 8. & Mie Instant (Dos) & 11,31 & 129.200 \\
\hline 9. & Mesin 120 PK 6 D 22 & 5.900 & 67.407 .500 \\
\hline 10. & Mesin kapal pengangkut 30 PK & 4.700 & 53.697 .500 \\
\hline 11. & Mesin Genset 10,5 PK (5000 KW) & 298 & 3.404 .650 \\
\hline 12. & Mesin pompa air & 200 & 2.285 .000 \\
\hline 13. & GPS fish finder 160 CI Garmin & 201 & 2.300 .000 \\
\hline 14. & Ikan Cakalang $(\mathrm{Kg})$ & 1,6 & 18.280 \\
\hline
\end{tabular}

Keterangan : *Kurs US $\$=$ Rp.11.425

Sumber : BPS Provinsi Sulawesi Tenggara, www.esdm, www.deperin, www.suarasurabaya.net, www.yespro.co.id, www.yamahaindonesia.com, www.indonetwork.co.id,

www.alibaba.com, global trades strart here TM (2014)

Perhitungan biaya pemulihan modal peralatan secara sosial pada dasarnya sama dengan perhitungan biaya pemulihan modal peralatan secara privat. Jika pada pemulihan modal peralatan secara privat dengan memperhitungkan umur ekonomis peralatan dengan suku bunga privat, maka pada pemulihan modal peralatan secara sosial dilakukan dengan memperhitungkan umur ekonomis peralatan dengan suku bunga sosial yang telah ditetapkan (Pearson et al, 2005)

\section{Analisis Daya Saing Usaha Perikanan Cakalang Berdasarkan Keunggulan Komparatif dan Kompetitif Di Kota kendari}

Sebagaimana cara yang telah disajikan dalam metode penelitian, untuk menentukan tingkat keunggulan komparatif dan kompetitif usaha perikanan cakalang pada alat tangkap purse seine $\geq 30$ GT di Kota Kendari 
menggunakan analisis PAM (Policy Analisis Matrix). Secara rinci disajikan pada Tabel 4 dengan alat tangkap purse seine $\geq 30 \mathrm{GT}$.

Tabel 4. Perhitungan Matriks Analisis Kebijakan (Model PAM) Usaha Perikanan Cakalang dengan Alat Tangkap Purse seine $\geq 30$ GT di Kota Kendari pada Tahun 2014.

\begin{tabular}{lccccc}
\hline \multicolumn{1}{c}{ Uraian } & $\begin{array}{c}\text { Penerimaan } \\
(\mathrm{Rp} / \mathrm{ha})\end{array}$ & $\begin{array}{c}\text { Biaya input } \\
\text { Tradable }(\mathrm{Rp}) \\
(57 \%)\end{array}$ & $\begin{array}{c}\text { Biaya input } \\
\text { non Tradable } \\
(\mathrm{Rp})(57 \%)\end{array}$ & $\begin{array}{c}\text { Keuntungan } \\
(\mathrm{Rp})\end{array}$ \\
\hline $\begin{array}{l}\text { Harga } \\
\begin{array}{l}1 \\
\text { Harga }\end{array}\end{array}$ Privat & 16.740 .000 & 5.455 .732 & 7.234 .048 & 4.041 .221 \\
$\begin{array}{l}\text { (2) } \\
\text { Dampak }\end{array}$ & 25.500 .600 & 8.733 .718 & 7.865 .822 & 8.901 .061 \\
$\begin{array}{l}\text { Kebijakan } \\
(3)=(1)-(2)\end{array}$ & $(8.760 .600)$ & $(3.277 .986)$ & $(622.774)$ & $(4.859 .840)$ \\
\hline
\end{tabular}

Keterangan : Nilai dalam kurung negatif

Kegagalan pasar dalam mentransfer harga output sebagai akibat sifat usaha perikanan yang beresiko tinggi terhadap kondisi alam, sehingga mengakibatkan nelayan tidak memiliki kapasitas penuh dalam menentukan harga. Berdasarkan hasil perhitungan penerimaan, harga privat, harga sosial dan dampak kebijakan pada unit usaha purse seine $\geq 30$ GT , dapat diperoleh indikator keuntungan yaitu PP (Privat Profitability) dan PS (Social Profitability), indikator daya saing yaitu PCR (Privat Cost Ratio) dan DRC (Domestic Resource Cost) indikator dampak kebijakan input yaitu IT (Input Transfer), FT (Faktor Transfers), NPCI (Nominal Protection Coefficient On Tradable Input). Indikator dampak kebijakan output yaitu OT (Output Transfer) dan NPCO (Nominal Protection Coefficient On Tradable Output) serta dampak kebijakan input output yaitu NT (Net Transfer), EPC (Effective Protection Coefficient), dan PC (Profitability Coeficient). Indikator daya saing komoditas ikan cakalang di Kota Kendari disajikan pada Tabel 5. 
Tabel 5. Indikator Daya Saing Usaha Perikanan Cakalang di Kota Kendari pada alat tangkap Purse seine $\geq 30$ GT , Tahun 2014

\begin{tabular}{|c|c|c|}
\hline \multirow[b]{2}{*}{ No. } & \multirow[b]{2}{*}{ Indikator } & Nilai (Rp) \\
\hline & & Purse seine \\
\hline & Analisis Keuntungan & \\
\hline 1. & PP (Private Profitability) & 4.041 .221 \\
\hline 2. & PS (Social Profitability) & 8.901 .061 \\
\hline & Daya Saing & \\
\hline 3. & PCR (Privat Cost Ratio) & 0,64 \\
\hline 4. & DRC (Domestic Resource Cost) & 0,47 \\
\hline & Dampak Kebijakan Input & \\
\hline 5. & IT (Input Transfer) & $(3.277 .986)$ \\
\hline 6. & FT (Faktor Transfer) & $(622.774)$ \\
\hline 7. & NPCI (Nominal Protection Coefficient On Tradable input) & 0,62 \\
\hline 8. & $\begin{array}{l}\text { Dampak Kebijakan Output } \\
\text { OT (Output Transfer) }\end{array}$ & $(8.760 .600)$ \\
\hline 9. & $\begin{array}{l}\text { NPCO (Nominal Protection Coefficient On Tradable } \\
\text { Output) }\end{array}$ & 0,65 \\
\hline 10. & Dampak Kebijakan Input-Output & $(4.859 .840)$ \\
\hline 11. & NT (Net Transfer) & 0,67 \\
\hline 12. & $\begin{array}{l}\text { EPC (Effective Protection Coefficient) } \\
\text { PC (Profitability Coeficient) }\end{array}$ & 0,45 \\
\hline
\end{tabular}

Keterangan : Tanda kurung menunjukkan angka negative

Hasil analisis PCR pada Tabel 3.5 juga menunjukkan bahwa koefisien PCR $<1$ pada unit penangkapan purse seine. Hal ini memberi arti bahwa biaya yang dikeluarkan oleh para nelayan untuk setiap satu rupiah penerimaan dari usaha perikanan cakalang hanya sebesar 0,64 rupiah pada alat tangkap purse seine $\geq 30$ GT. Nilai PCR dapat diminimalkan dengan menurunkan biaya faktor (domestik) dan input tradable. Dengan demikian usaha perikanan cakalang memiliki keunggulan kompetitif atau daya saing secara finansial.

Nilai keunggulan komparatif diukur dengan menggunakan keuntungan sosial (Social profit) dan DRC. Keuntungan sosial adalah keuntungan yang diperoleh jika terjadi pada pasar persaingan sempurna dimana tidak ada campur tangan pemerintah dan kegagalan pasar. Berbeda dengan analisis keuntungan privat, dalam analisis keuntungan ekonomi (sosial) komponen input output dapat dinilai dengan menggunakan harga sosial. Keuntungan sosial yang diperoleh dari ikan cakalang hasil tangkapan QE Journal | Vol.03 - No.04 December 2014 - 225 
nelayan dengan menggunakan alat tangkap purse seine $\geq 30$ GT adalah sebesar Rp8.901.061. Alat tangkap purse seine $\geq 30$ GT diketahui bernilai positif yang berarti pengusahaan penangkapan ikan cakalang menguntungkan secara ekonomi sehingga sudah mampu bersaing dengan usaha penangkapan ikan cakalang didaerah lain. Hasil analisis PAM menunjukkan tingkat profitabilitas privat usaha perikanan cakalang pada alat tangkap purse seine $\geq 30$ GT di Kota Kendari lebih kecil dibanding profitabilitas sosialnya. Berdasarkan kedua indikator daya saing tersebut maka dapat disimpulkan bahwa usaha perikanan cakalang di Kota Kendari dengan layak diusahakan karena memiliki keunggulan kompetitif dan komparatif.

\section{Analisis Dampak Kebijakan Pemerintah Terhadap Daya Saing}

Suatu kebijakan pemerintah dalam aktivitas ekonomi dapat memberikan dampak positif maupun negatif terhadap perilaku ekonomi. Dampak kebijakan juga dapat menurunkan atau meningkatkan produksi maupun produktifitas dari aktivitas ekonomi.

\section{Dampak Kebijakan Harga Input}

Hasil perhitungan NPCI seperti yang ada pada Tabel. 3.6 menunjukkan nilai yang lebih kecil dari satu yakni 0,62. Hal ini menunjukkan bahwa terdapat campur tangan pemerintah berupa kebijakan atas harga input tradable, sehingga harga yang dibayarkan oleh nelayan terhadap inputinput tersebut menjadi lebih rendah dari harga yang seharusnya. Nilai NPCI pada 0,62 artinya nelayan ikan cakalang hanya membayar input tradable sebesar $62 \%$ dari harga sosial yang seharusnya atau memperoleh subsidi sebesar $38 \%$. Terlihat pula bahwa secara umum, kebijakan input dan kinerja pasar input yang berjalan berpihak kepada usaha perikanan cakalang. Hal ini disebabkan karena keterlibatan pemerintah dalam memberikan subsidi dan pungutan pajak. Nilai transfer faktor (FT) digunakan untuk melihat kebijakan pemerintah terhadap input domestik (non tradable) yaitu sarana produksi (air bersih, es balok, umpan) tenaga kerja, dan peralatan.

Hasil PAM yang berkaitan dengan FT menunjukkan nilai FT yang lebih kecil dari nol atau negatif yaitu Rp-622.774. Secara teori jika nilai FT lebih besar dari nol berarti ada kebijakan pemerintah yang melindungi produsen input domestik, namun yang terjadi pada usaha perikanan cakalang di

QE Journal | Vol.03 - No.04 December 2014 - 226 
Kota Kendari nilai FT lebih kecil dari satu. Hal ini menunjukkan bahwa pemerintah tidak sepenuhnya berpihak pada penggunaan input domestik dalam hal ini diperkirakan dari penetapan upah minimum tenaga kerja (UMP), dimana nelayan pemilik kapal membayar upah tenaga kerja masih dibawah upah yang ditetapkan pemerintah.

\section{Dampak Kebijakan Harga Output}

Berdasarkan hasil perhitungan pada Tabel.3.6 maka nilai OT komoditas ikan cakalang di Kota Kendari nilainya negatif atau lebih kecil dari nol yakni negatif Rp8.760.000. Nilai OT yang negatif mengindikasikan bahwa harga sosial ikan cakalang jauh lebih baik dibandingkan dengan harga privat yang diterima nelayan ikan cakalang. Dapat dikatakan bahwa konsumen dalam negeri membeli ikan cakalang dengan harga yang lebih rendah dari harga yang seharusnya dibayar dibandingkan apabila pasar tidak terdistorsi atau tanpa kebijakan pemerintah. Namun kebijakan ini menguntungkan konsumen dalam negeri, sehingga menimbulkan transfer (insentif) dari nelayan kepada konsumen.

Untuk nilai NPCO yang lebih kecil dari satu yakni sebesar 0,65 (Tabel 3.6) dapat diartikan bahwa nelayan ikan cakalang menerima harga lebih rendah atau murah dari harga yang seharusnya atau penerimaan domestik ikan cakalang lebih rendah $66 \%$ dari penerimaan sosialnya. Hal ini mengindikasikan bahwa kebijakan pemerintah dalam memproteksi nelayan ikan cakalang masih belum efektif, sehingga penerimaan yang diterima oleh nelayan menjadi lebih rendah.

\section{Dampak Kebijakan Input-Output}

Transfer bersih atau NT yang menggambarkan tambahan surplus produsen atau berkurangnya surplus produsen yang diakibatkan oleh kebijakan pemerintah. Indikator ini dihitung dari hasil pengurangan antara keuntungan privat yang diterima produsen dengan keuntungan sosial menunjukkan angka negatif yakni Rp-4.859.840. Nilai transfer bersih yang negatif berarti kebijakan pemerintah yang ada terhadap input dan output masih belum memberikan insentif ekonomi untuk meningkatkan produksi, karena terjadi pengurangan surplus produsen sebesar Rp4.859.840. Hal ini mengidentifikasikan telah terjadi pengalihan surplus dari produsen ke pihak lain. Selain itu nilai transfer bersih yang negatif juga mengindikasikan bahwa harga yang diterima para nelayan ikan cakalang 
lebih rendah daripada nilai ekspor ikan cakalang dalam hal ini ditunjukkan oleh nilai fob. Hal ini dianggap wajar karena sebagian dari harga fob tersebut jatuh ke tangan para pedagang ikan cakalang dalam bentuk biaya transport, biaya sortasi, biaya pengepakan, biaya penyimpanan, biaya retribusi, upah tenaga kerja dalam proses bongkar muat di pelabuhan dan keuntungan pedagang.

Hasil analisis memperlihatkan nilai PC yang lebih kecil dari satu yakni 0,45 . Hal ini menunjukkan keuntungan yang diterima oleh para nelayan ikan cakalang berkurang $45 \%$ pada purse seine $\geq 30$ GT dibandingkan dengan keuntungan yang seharusnya mereka terima. Hal ini mengindikasikan bahwa dampak kebijakan pemerintah kenyataannya menyebabkan keuntungan yang diterima nelayan (privat) lebih rendah dari keuntungan yang seharusnya diterima (sosial).

\section{SIMPULAN DAN SARAN}

Berdasarkan pada hasil dan pembahasan maka kesimpulan penelitian ini dirumuskan sebagai berikut:

1. Usaha perikanan cakalang di Kota Kendari pada alat tangkap purse seine $\geq 30$ GT memiliki keunggulan secara komparatif dan kompetitif.

2. Secara keseluruhan kebijakan pemerintah yang mempengaruhi usaha perikanan cakalang di Kota Kendari dengan menggunakan alat tangkap purse seine dari segi pendapatan masih belum memberikan insentif (perlindungan) kepada nelayan. Kebijakan pemerintah yang berkaitan dengan harga input-output berimplikasi pada keuntungan yang diterima nelayan (privat) lebih rendah dari keuntungan yang seharusnya diterima (sosial).

\section{DAFTAR PUSTAKA}

Amrun, 2011. Analisis Daya Saing Komoditi Jeruk Siam di Kabupaten Konawe Selatan. Tesis, Pascasarjana Universitas Haluoleo, Kendari.

Bank Indonesia, 2014. Nilai Kurs Transaksi Bank Indonesia. Kendari, Sulawesi Tenggara.

BPS, 2013. Sulawesi Tenggara Dalam Angka. Kendari.

Cahya, 2010. Analisis Daya Saing Ikan Tuna Indonesia di Pasar Internasional. Skripsi, Institut Pertanian Bogor. Bogor.

QE Journal | Vol.03 - No.04 December 2014 - 228 
Deperin, 2014. Daftar Harga Pangan dan Kebutuhan Pokok, http://www.deperin.go.id. Mei 2014.

Gittinger, JP. 1986. Analisis Ekonomi Proyek-proyek Pertanian Edisi Kedua (Terjemahan). Universitas Indonesia Press. Jakarta.

Indonetwork PT. 2014. Perdagangan dalam dan Luar Negeri. http://www.indonetwork.co.id. Mei 2014

IndoTrading PT. 2014. Situs Perdagangan Nomor Satu di Indonesia, http://www.google.com. April 2014.

Ira. 2014. Kajian Kualitas Perairan Berdasarkan Parameter Fisika Dan Kimia Di Pelabuhan Perikanan Samudera Kendari Sulawesi Tenggara. Aquasains. Jurnal Ilmu Perikanan dan Sumberdaya Perairan, 1 (3): 119-123

Kementerian Keuangan RI. 2014, Tingkat Suku Bunga Nasional. Kementerian Keuangan RI, Kendari, Sulawesi Tenggara.

Kementrian Energi Sumber Daya Mineral RI, 2014. Daftar Harga Bahan Bakar Minyak Indonesia bersubsidi, http://www.esdm.go.id

KKP, 2012. Rencana Pengelolaan Perikanan Tuna Nasional. Direktorat Jenderal Perikanan Tangkap. Kementerian Kelautan dan Perikanan. Jakarta.

Kusumastanto. 2011. Kebijakan Dan Strategi Peningkatan Produktivitas Dan daya Saing Produk Perikanan Nasional. Agrinex Conference and Expo, Jakarta.

Lopulalan, Y. 2010. Analisis Dampak Kemitraan Perikanan Tangkap Terhadap Kondisi Ekonomi Wilayah. Jurnal "Amanisal” PSP FPIK UnpattiAmbon 1 (1) : 56 - 66.

Pearson, et.al. 2005. Aplikasi Policy Analysis Matrix Pada Pertanian Indonesia. Buku Obor. Bogor-Indonesia.

Sekretariat Kabinet Indonesia. 2014. Daftar Harga Kebutuhan Pokok Indonesia, http://www.sekretariatkabinetindonesia.go.id. Januari 2014.

Suara Surabaya. 2013. Harga Beras dan kebutuhan Pokok Lainnya, http://www.suarasurabaya.net. Desember 2013.

Sugiyanto, FX. 2004. Peningkatan Daya Saing Ekonomi Indonesia. Jurnal Dinamika Ekonomi dan Bisnis. 1(1) : 14-27

Yamaha Indonesia PT. Penjualan Mesin Diesel dan sparepart Terkemuka di Indonesia, http://www.yamahaindonesia.com. Oktober 2013. 